\title{
Relationship between mRNA of immune factors expressed by milk somatic cells and bacteria present in healthy lactating Holstein cows
}

\author{
Hiromichi Ohtsuka $^{1}$, Honami Hirose ${ }^{2}$, Kenji Murakami ${ }^{3}$, \\ Ryo Murata $^{1}$, Toshihide Kato ${ }^{1}$, Motoshi Tajima ${ }^{1}$ \\ ${ }^{1}$ School of Veterinary Medicine, Rakuno Gakuen University, \\ Ebetsu, Hokkaido 069-8501, Japan \\ ${ }^{2}$ Federation of Agricultural Mutual Relief Association, \\ Bekkai, Hokkaido 086-0292, Japan \\ ${ }^{3}$ Federation of Agricultural Mutual Relief Association, \\ Fukagawa, Hokkaido 073-0022, Japan \\ ohtsuka@rakuno.ac.jp
}

Received: January 9, 2019

Accepted: July 2, 2019

\begin{abstract}
Introduction: The characteristics of immune factors in somatic cells from lactating dairy cows and their association with commensal bacteria in normal milk have not been clarified. This study investigated the relationship between the pathogenic bacteria in milk and somatic cell immune factors in healthy lactating cows. Material and Methods: In total 44 healthy Holstein cows were studied on one farm. Milk samples were collected aseptically using a cannula and these samples were cultured for detection of bacteria and analysis of mRNA of immune factors expressed by somatic cells. Cows were divided into two groups based on the microbial status of their milk samples: 12 cows showed bacteria in cultures (positive group), and the other 32 cows did not (negative group). Results: The mRNA levels of IL-6, lactotransferrin, and cathelicidin expressed by somatic cells after milking decreased significantly compared to those before milking in both groups $(\mathrm{P}<0.05)$. There were significantly lower mRNA levels of IL-6 and cathelicidin in the positive group compared to those in the negative group before milking. Conclusion: These results suggest that mRNA levels of IL- 6 and cathelicidin expressed by the somatic cells may be affected by the presence of bacteria in healthy lactating dairy cows.
\end{abstract}

Keywords: cows, milk, bacteria, immune factor, somatic cells.

\section{Introduction}

The mucosal immune system has direct contact with the external antigenic environment. In mucosal tissue, several cells co-habit with major non-pathogenic bacteria in a symbiotic relationship. The microbiota interacts with its host both locally and systemically, and the immune system develops a collaborative symbiosis with antigens of the healthy microbiota.

The mammary gland is one of the mucosal organs. It is thought that the cellular and soluble immune components associated with mammary tissues can also play an important role in protecting the gland from infectious diseases (22). The antibacterial factors, such as $\beta$-defensins, cathelicidins, lactoferrin, natural killer cells, immunoglobulins, cytokines, and/or many other factors are dramatically upregulated to prevent the infection by pathogens of the mucosal tissue of the mammary gland $(14,18)$. Pentraxin-3 is an inflammatory marker that activates the classical complement pathway and facilitates pathogen recognition by macrophages, and elastase is known as an anti-bacterial enzyme, increased in mastitic milk $(2,25)$. Caspase-3 is one of the anti-inflammatory factors inhibiting the release of prosurvival and proinflammatory mediators by cleaving the transcription factor $\mathrm{NF}-\mathrm{\kappa B}$; through a mechanism involving this factor a mastitic pathogen induces apoptosis in 
mammary epithelial cells as previously reported (24). Raw milk aseptically drawn from healthy glands has antimicrobial activities against mastitis-causing bacteria (5). Although the immune system has preventive capability against bacterial infection in the mammary gland of dairy cows, mastitis nevertheless occurs when bacteria invade teat canals, often from the milking equipment, milking personnel, manure contamination, or dirty stalls.

A previous report described the lactating cow udder as inhabited by "normal bacterial flora" (16). However, bacteria were not found in the milk from healthy quarters of a cow sampled using a cannula introduced through the teat canal (15). Therefore, the mammary glands of a cow have also been considered to be bacteria-free. In humans, the existence of a commensal microbiota of milk and mammary tissue was reported previously (7). However, the presence of commensal microbiota in the mammary gland of dairy cows without mastitis has not been reported. In particular, the characteristics of immune factors in somatic cells from lactating dairy cows and their association with commensal bacteria in normal milk have not been clarified. The objective of this study was to investigate the association between bacteria and immune factors of somatic cells present in the gland cistern of healthy dairy cows.

\section{Material and Methods}

A total of 44 healthy lactating Holstein dairy cows were used. The cows were all on the same farm. Milk samples in $50 \mathrm{~mL}$ volume were collected aseptically before and after the morning milking from the mammary gland cistern of the right front quarter using a cannula after disinfection of the teat end. Immediately after sampling, all milk samples were negative in a California mastitis test. These samples were cultured for bacteria detection and analysed for mRNA of immune factors expressed by somatic cells. The cows were divided into two groups; bacteria were detected after culturing milk from 12 cows, and these cows formed the (positive group), while they were not detected in the other 32 cows, which were the negative group. The parity and days after calving were $2.25 \pm 0.25$ (mean \pm standard error of the mean $( \pm \mathrm{SE}))$ and $235.08 \pm 40.25$ in the positive group and $2.28 \pm 0.26$ and $190.16 \pm 18.44$ in the negative group, respectively. There were seven pairs of paternal sisters and four pairs of maternal sisters in the examined cows, but no bias by descent from a specific lineage was found.

Milk samples were centrifuged at $400 \times \mathrm{g}$ for $10 \mathrm{~min}$ at room temperature within 1 to $2 \mathrm{~h}$ of collection. The time from collecting milk to isolating mRNA varied in each cow. After centrifuging, sedimented somatic cells were washed twice with PBS by centrifugation at $400 \times \mathrm{g}$ for $5 \mathrm{~min}$. For mRNA isolation and cDNA synthesis, a SuperPrep cell lysis and RT kit for qPCR (Toyobo Ltd, Japan) was used. Each sample had $2 \times 10^{6}$ cells mixed with $50 \mu \mathrm{L}$ of cell lysis mixture (including
gDNA remover) to react for $5 \mathrm{~min}$ before the stop solution was added. Then $8 \mu \mathrm{L}$ of each mRNA solution extracted from $32 \mu \mathrm{L}$ of reaction mixture was added. PCR was used to synthesise CDNA, and a real-time PCR was performed using THUNDERBIRD SYBR qPCR Mix (Toyobo) on an ABI prism 7300 Sequence Detector (Applied Biosystems, USA). The following genes were selected: $\beta$-actin, interleukin-6 (IL-6), lysosome, lactotransferrin, defensin- $\beta 3$, cathelicidin, pentraxin-3, caspase-3, and elastase. Primers were designed using the freely available web-based Primer3 programme (21) and are listed in Table 1. The cycle threshold $(\mathrm{Ct})$ values define the PCR cycle threshold at which amplified products were detected. The final quantification of immune-related mRNA molecules was carried out using the $\mathrm{Ct}$ method as reported previously (11). The calibrator samples used were those with the lowest amount of mRNA for each gene of all the samples used for the respective mRNA.

To evaluate bacteria, milk samples were plated onto trypticase soy agar plates supplemented with $5 \%$ of sheep blood. The plates were incubated aerobically in $5 \% \mathrm{CO}_{2}$ for $24 \mathrm{~h}$ or anaerobically in the Anaeropack system (Mitsubishi Gas Chemical, Japan) for $48 \mathrm{~h}$.

Statistical analysis for each parameter was performed using the Mann-Whitney U test in order to determine the difference between two groups, and using the Wilcoxon signed-rank test in order to determine the difference between the variables before and after milking in each group. The differences were considered significant at $\mathrm{P}<0.05$. Data were expressed as mean \pm standard error. Correlations among genes were analysed using Spearman's rank correlation test and significance was determined at $\mathrm{P}<0.01$ or $\mathrm{P}<0.05$.

\section{Results}

The numbers of bacteria in aerobic and anaerobic cultures in $\mathrm{CFU} / \mathrm{ml}$ were $89.17 \pm 25.0$ and $82.25 \pm 31.28$ before milking, and $34.08 \pm 16.51$ and $45.08 \pm 0.68$ after milking, respectively, in the positive group. Strains of detected bacteria and their positive sample numbers are shown in Table 2. For samples obtained before milking, five out of ten samples in aerobic culture and three out of ten samples in anaerobic culture contained two strains or more. For samples obtained after milking, two out of ten samples in aerobic and anaerobic cultures contained two strains or more.

Table 3 shows the mRNA of immune factors expressed by somatic cells relative to the $\beta$-actin housekeeping gene. In this study, mRNA levels of IL-6, lactotransferrin, and cathelicidin in the somatic cells after milking decreased significantly compared to those before milking in two groups, and a significantly lower mRNA level of caspase-3 after milking was found compared to that before milking in the negative group $(\mathrm{P}<0.05)$. The mRNA level of IL-6 in the positive group was significantly lower both before and after milking compared to that in the negative group $(\mathrm{P}<0.05)$. There 
was a significantly lower mRNA level of cathelicidin in the positive group compared to that in the negative group before milking $(\mathrm{P}<0.05)$. The mRNA level of IL-6 was positively correlated with the cathelicidin mRNA levels before milking $(\mathrm{R}=0.712, \mathrm{P}<0.01)$ and after milking
$(\mathrm{R}=0.522, \mathrm{P}<0.05)$ in the somatic cells. However, no correlation was found with an index over 0.5 in the other factors. There was no relationship between the mRNA levels of immune factors and parity or days after calving.

Table 1. Primers used for real-time PCR

\begin{tabular}{|c|c|c|c|c|}
\hline Gene & $\begin{array}{l}\text { Accession } \\
\text { number }\end{array}$ & $\begin{array}{l}\text { Product } \\
\text { length }\end{array}$ & $\begin{array}{l}\text { Primer } \\
\text { designation }\end{array}$ & Sequence $\left(5^{\prime}-3^{\prime}\right)$ \\
\hline \multirow{2}{*}{$\beta$-actin } & \multirow{2}{*}{ NM_173979.3 } & \multirow{2}{*}{76} & Forward & CCCAGATCATGTTCGAGACC \\
\hline & & & Reverse & GAGGCATACAGGGACAGCAC \\
\hline \multirow{2}{*}{ interleukin-6 } & \multirow{2}{*}{ NM_173923.2 } & \multirow{2}{*}{102} & Forward & AGATCCTGAAGCAAAAGATCGC \\
\hline & & & Reverse & TTGCGTTCTTTACCCACTCGT \\
\hline \multirow{2}{*}{ lysozyme } & \multirow{2}{*}{ NM_001078159.1 } & \multirow{2}{*}{104} & Forward & TTCGGTCGCTGTCCAAGGCAAGGT \\
\hline & & & Reverse & TCCAGTTTGCCAGGCTGATTCCCC \\
\hline \multirow{2}{*}{ lactotransferrin } & \multirow{2}{*}{ NM_180998.2 } & \multirow{2}{*}{136} & Forward & CACCGAGCACTGGATAAAGGG \\
\hline & & & Reverse & AGCCAGACACAGTCCAAGGG \\
\hline \multirow{2}{*}{ defensin- $\beta 3$} & \multirow{2}{*}{ NM_001282581.1 } & \multirow{2}{*}{70} & Forward & GCATACAAGTGACTGCCCCTG \\
\hline & & & Reverse & ACTGAACCTCTTCCCTGTGTG \\
\hline \multirow{2}{*}{ cathelicidin } & \multirow{2}{*}{ Y09472.1 } & \multirow{2}{*}{70} & Forward & GAAAGACTCTCCTACCCTGCCC \\
\hline & & & Reverse & CTCTAAGGGACACACAGCCAGG \\
\hline \multirow{2}{*}{ pentraxin-3 } & \multirow{2}{*}{ NM_001076259.2 } & \multirow{2}{*}{80} & Forward & GCAGAGTCCTGTCACATCCG \\
\hline & & & Reverse & ACATACTGTGCTCCTCCGTG \\
\hline \multirow{2}{*}{ caspase-3 } & \multirow{2}{*}{ NM_001077840.1 } & \multirow{2}{*}{148} & Forward & CAGGAGTGGAGTCCAGCAGA \\
\hline & & & Reverse & TCCAGAGTCCATTGATTTGCTTC \\
\hline \multirow{2}{*}{ elastase } & \multirow{2}{*}{ NM_001105653.1 } & \multirow{2}{*}{119} & Forward & TTGCCTCTGTCGCCAAGTTT \\
\hline & & & Reverse & ACAGCCTTTCTAGTGGGTCC \\
\hline
\end{tabular}

Table 2. Major bacteria detected before and after milking in the positive group $(n=12)$

\begin{tabular}{lllll}
\hline & \multicolumn{2}{c}{ aerobic culture } & \multicolumn{2}{c}{ anaerobic culture } \\
& before & after & before & after \\
\hline Aerococcus viridans & 3 & 1 & 2 & 1 \\
Staphylococcus chromogenes & 1 & 1 & 1 & 1 \\
Staphylococcus haemolyticus & 3 & 2 & 2 & 1 \\
Staphylococcus xylosus & 3 & 3 & 4 & 4 \\
Streptococcus dysgalactiae & 0 & 1 & 1 & 1 \\
\hline
\end{tabular}

Numbers indicate the number of cows

Table 3. Relative mRNA level of immune factors expressed by milk cells compared to $\beta$-actin expression

\begin{tabular}{|c|c|c|c|c|}
\hline & & Positive group & Negative group & \\
\hline \multirow{2}{*}{ interleukin-6 } & before & $11.80 \pm 1.17^{\mathrm{a}}$ & $16.33 \pm 0.68^{\mathrm{a}}$ & * \\
\hline & after & $7.97 \pm 1.12^{\mathrm{b}}$ & $11.98 \pm 0.71^{b}$ & * \\
\hline \multirow{2}{*}{ lysozyme } & before & $5.27 \pm 0.34$ & $5.39 \pm 0.18$ & \\
\hline & after & $5.13 \pm 0.25$ & $5.31 \pm 0.25$ & \\
\hline \multirow{2}{*}{ lactotransferrin } & before & $9.28 \pm 1.74^{\mathrm{a}}$ & $11.32 \pm 0.75^{\mathrm{a}}$ & \\
\hline & after & $7.60 \pm 0.97^{b}$ & $8.42 \pm 0.61^{\mathrm{b}}$ & \\
\hline \multirow{2}{*}{ defensin- $\beta 3$} & before & $3.86 \pm 0.27$ & $2.99 \pm 0.21$ & \\
\hline & after & $3.60 \pm 0.37$ & $3.78 \pm 0.18$ & \\
\hline \multirow{2}{*}{ cathelicidin } & before & $6.27 \pm 0.56^{\mathrm{a}}$ & $8.24 \pm 0.42^{\mathrm{a}}$ & * \\
\hline & after & $4.61 \pm 0.74^{\mathrm{b}}$ & $5.86 \pm 0.39^{b}$ & \\
\hline \multirow{2}{*}{ pentraxin-3 } & before & $4.31 \pm 0.24$ & $4.97 \pm 0.22$ & \\
\hline & after & $3.84 \pm 0.35$ & $4.20 \pm 0.20$ & \\
\hline \multirow{2}{*}{ caspase- 3} & before & $13.84 \pm 1.23$ & $15.22 \pm 0.30^{\mathrm{a}}$ & \\
\hline & after & $12.86 \pm 0.92$ & $13.49 \pm 0.66^{b}$ & \\
\hline \multirow{2}{*}{ elastase } & before & $10.07 \pm 0.96$ & $11.19 \pm 0.33$ & \\
\hline & after & $10.043 \pm 0.45$ & $10.71 \pm 0.25$ & \\
\hline
\end{tabular}

Results are expressed as the mean \pm SE. Different letters indicate significance at $\mathrm{P}<0.05$ within the same group, and an asterisk indicates the significant difference at $\mathrm{P}<0.05$ between the two groups 


\section{Discussion}

Although microbiota of the udder could not be determined in this study, bacteria were detected in the gland cisterns of some cows before and after milking. It is suggested that bacterial flora is not always found inside of the mammary gland of all cows. The isolated bacteria are known as causative pathogens of the subclinical mastitis, but the pathogenicity of them is low $(9,13,19)$. Once very few bacteria have gained access to the teat cistern of uninflamed glands, bacterial multiplication takes place and infection ensues (12). When the defence system of the mammary gland is compromised, it is common for the infecting bacteria to reach concentrations above $10^{6}$ to $10^{8} \mathrm{cfu} / \mathrm{mL}$ in milk $(15,16)$. Since human milk from healthy women contains $10^{3}$ to $10^{4} \mathrm{cfu} / \mathrm{mL}$ of diverse bacteria (7), the presence of a few bacteria may be a normal condition in the mammary gland of lactating dairy cows.

Human breast milk contains numerous inflammatory factors, such as C-reactive protein, IL-6, and TNF- $\alpha$ (4). In cows during mid and late lactation, cytokine mRNA profiles in the mammary gland cells showed significant elevation of IL-12 transcriptional activity, but a significant change of IL- 6 was not found (3). We found a significant correlation between IL-6 and cathelicidin in the somatic cells. Since human cathelicidin elicits modest up-regulation of IL-6 gene expression in peripheral blood mononuclear cells (26), increased IL- 6 may be affected by the cathelicidin of the somatic cells in cows. This peptide along with $\beta$-defensin and lactotransferrin are antimicrobial factors of innate immunity, and these factors are the arsenal of the leukocytes for defence against bacterial infection in the mammary gland (6). The positive group showed significantly lower mRNA levels of IL-6 and cathelicidin in the somatic cells before milking compared to those in the negative group before milking. It is possible that the more these immune factors are present, the less likely the bacterial growth in the mammary gland of the lactating dairy cows is. Lactoferrin was reported effective in increasing the cure rate through the induction of innate immunity in cows (8). Since the mRNA levels of IL-6, cathelicidin, and lactotransferrin in the somatic cells were significantly higher in both groups before milking than those after milking, the defensive effect of these immune factors is suggested to be higher before milking than after milking in the mammary gland. On the other hand, caspase is known as a family of cysteine aspartyl proteases inducing cell apoptosis (20). Ward et al. (23) indicated that inhibition of NF- $\mathrm{BB}$ in granulocytes accelerates apoptosis in a caspase-3-dependent manner in antiinflammatory reactions. Although a significantly increased mRNA level of caspase-3 of the somatic cells was detected before milking compared to that after milking in the negative group, this difference was not found in the positive group. It is possible that the consistency in expression of caspase-3 mRNA between the samples taken before and after milking is due to the presence of live bacteria in the udder, but further study is needed to clarify the mechanism of this caspase- 3 mRNA expression downregulation.

Research in humans lead to the contention that bacteria from the gut microbiota would reach the mammary gland by an endogenous route (10). The most common species identified from body samples were S. chromogenes, $S$. xylosus, and S. haemolyticus (1). It is suggested that one likely origin of microbiota in the raw milk may be the teat skin bacteria that contaminate it during milking. IL-6 and cathelicidin are known as inflammatory immune factors, and these factors increased in cows with mastitis $(6,17)$. Production of appropriate levels of these immune factors may inhibit the growth of bacteria invading the mammary gland in lactating dairy cows, because we found significant differences in mRNA levels of IL-6 and cathelicidin between two groups. But we have not confirmed whether the same results would be observed in all quarters, and it is also unclear why IL- 6 and cathelicidin mRNA expression in somatic cells decreased in the negative group. Further study is needed to clarify this.

In conclusion, findings from the present study indicated that mRNA levels of IL- 6 and cathelicidin mRNA expression in the somatic cells before milking may be affected by presence of bacteria in the mammary gland of lactating healthy dairy cows.

Conflict of Interests Statement: The authors declare that there is no conflict of interests regarding the publication of this article.

Financial Disclosure Statement: The work was supported by a grant from the Meiji Seika Pharma Co.

Animal Rights Statement: The procedures used in the present study were in accordance with the principles and guidelines for animal use set by the Animal Experiment and Care Committee of Rakuno Gakuen University, Ebetsu, Japan.

\section{References}

1. Adkins P.R.F., Dufour S., Spain J.N., Calcutt M.J., Reilly T.J., Stewart G.C., Middleton J.R.: Molecular characterization of nonaureus Staphylococcus spp. from heifer intramammary infections and body sites. J Dairy Sci 2018, 101, 5388-5403.

2. Albenzio M., Santillo A., Kelly A.L., Caroprese M., Marino R., Sevi A.: Activities of indigenous proteolytic enzymes in caprine milk of different somatic cell counts. J Dairy Sci 2015, 98, 75877594.

3. Alluwaimi A.M., Cullor J.S.: Cytokines gene expression patterns of bovine milk during middle and late stages of lactation. J Vet Med B Infect Dis Vet Public Health 2002, 49, 105-110.

4. Durilova M., Stechova K., Petruzelkova L. Stavikova V., Ulmannova T., Nevoral J.: Is there any relationship between cytokine spectrum of breast milk and occurrence of eosinophilic colitis? Acta Paediatr 2010, 99, 1666-1670. 
5. Fang W., Pyörälä S.: Mastitis-causing Escherichia coli: serum sensitivity and susceptibility to selected antibacterials in milk. J Dairy Sci 1996, 79, 76-82.

6. Isobe N.: Control mechanisms for producing antimicrobial factors in ruminant mammary gland. Anim Sci J 2017, 88, 937-943.

7. Jeurink P.V., van Bergenhenegouwen J., Jimenez E., Knippels L.M., Fernandez L., Garssen J., Knol J., Rodriguez J.M., Martin R.: Human milk: a source of more life than we imagine. Benef Microbes. 2013, 4, 417-430.

8. Kai K., Komine Y., Komine K., Asai K., Kuroishi T., Kozutsumi T., Itagaki M., Ohta M., Kumagai K.: Effects of bovine lactoferrin by the intramammary infusion in cows with staphylococcal mastitis during the early non-lactating period. J Vet Med Sci 2002, 64, 873-878.

9. Lasagno M., Ortiz M., Vissio C., Yaciuk R., Bonetto C., Pellegrino M., Bogni C., Odierno L., Raspanti C.: Pathogenesis and inflammatory response in experimental caprine mastitis due to Staphylococcus chromogenes. Microb Pathog 2018, 116, 146-152.

10. Martín R., Langa S., Reviriego C., Jiménez E., Olivares M., Boza J., Jiménez J., Fernández L., Xaus J., Rodríguez M.: The commensal microflora of human milk: new perpectives for food bacteriotherapy and probiotics. Trends Food Sci Technol 2004, $15,121-127$

11. Maeda Y., Ohtsuka H., Tomioka M., Oikawa M.: Effect of progesterone on $\mathrm{Th} 1 / \mathrm{Th} 2 / \mathrm{Th} 17$ and Regulatory $\mathrm{T}$ cell-related genes in peripheral blood mononuclear cells during pregnancy in cows. Vet Res Commun 2012, 37, 43-49.

12. Metzger S.A., Hernandez L.L., Skarlupka J.H., Suen G., Walker T.M., Ruegg P.L.: Influence of sampling technique and bedding type on the milk microbiota: results of a pilot study. J Dairy Sci 2018, 101, 6346-6356.

13. Murdough P.A., Deitz K.E., Pankey J.W.: Effects of freezing on the viability of nine pathogens from quarters with subclinical mastitis. J Dairy Sci 1996, 79, 334-336.

14. Pawlik A., Sender G., Korwin-Kossakowska A.: Bovine lactoferrin gene polymorphism and expression in relation to mastitis resistance - a review. Anim Sci Pap Rep 2009, 27, $263-271$
15. Pyörälä S., Jousimies-Somer H., Mero M.: Clinical, bacteriological and therapeutic aspects of bovine mastitis caused by aerobic and anaerobic pathogens. Br Vet J 1992, 148, 54-62.

16. Rainard P., Riollet C.: Mobilization of neutrophils and defense of the bovine mammary gland. Reprod Nutr Dev 2003, 43, 439-457.

17. Sakemi Y., Tamura Y., Hagiwara K.: Interleukin-6 in quarter milk as a further prediction marker for bovine subclinical mastitis. J Dairy Res 2011, 78, 118-121.

18. Sordillo L.M., Streicher K.L.: Mammary gland immunity and mastitis susceptibility. J Mammary Gland Biol Neoplasia 2002, 7 , 135-146.

19. Špaková T., Elečko J., Vasil M., Legáth J., Pristaš P., Javorský P.: Limited genetic diversity of Aerococcus viridans strains isolated from clinical and subclinical cases of bovine mastitis in Slovakia. Pol J Vet Sci 2012, 15, 329-335.

20. Thornberry N.A., Lazebnik Y.: Caspases: enemies within. Science 1998, 281, 1312-1316.

21. Untergasser A., Cutcutache I., Koressaar T., Ye J., Faircloth B.C., Remm M. Rozen S.G.: Primer3-new capabilities and interfaces. Nucleic Acids Res. 2012, 40, 15:e115.

22. Vorbach C., Capecchi M.R., Penninger J.M.: Evolution of the mammary gland from the innate immune system? Bio Essays 2006, 28, 606-616.

23. Ward C., Chilvers E.R., Lawson M.F., Pryde J.G., Fujihara S., Farrow S.N., Haslett C., Rossi A.G.: NF-kappaB activation is a critical regulator of human granulocyte apoptosis in vitro. J Biol Chem 1999, 274, 4309-4318.

24. Wesson C.A., Deringer J., Liou L.E., Bayles K.W., Bohach G.A., Trumble W.R.: Apoptosis induced by Staphylococcus aureus in epithelial cells utilizes a mechanism involving caspases 8 and 3 . Infect Immun 2000, 68, 2998-3001.

25. Wirestam L., Enocsson H., Skogh T., Eloranta M.L., Rönnblom L., Sjöwall C., Wetterö J.: Interferon- $\alpha$ coincides with suppressed levels of pentraxin-3 (PTX3) in systemic lupus erythematosus and regulates leucocyte PTX3 in vitro. Clin Exp Immun 2017, 189, 83-91.

26. Wu H., Zhang G., Minton J.E., Ross C.R., Blecha F.: Regulation of cathelicidin gene expression: induction by lipopolysaccharide, interleukin-6, retinoic acid, and Salmonella enterica serovar Typhimurium infection. Infect Immun 2000, 68, 5552-5558. 